\title{
The Five Floor Elevator Control System Design Based on S7-300 PLC Jiaxiong Wen
}

Sichuan Information Technology College

Keywords: Elevator; PLC; Automatic control;

Abstract. This paper describes the situation of China's elevator industry. And apply technology of programmable logic controller to control system for five floor elevator. This technology not only improves the elevator reliability, maintainability, and flexibility while greatly extending the life of the elevator, shortens the development cycle of the elevator.

This paper in-depth analyzes the working principle of the elevator based on introducing the basic structure of the elevator. It describes advantage and disadvantage of PLC, focusing on analysis of hardware design and software design of the elevator. Studied and proposed the scheme of realization of elevator control system design based on PLC, and finally summarized and discussed the research content of this paper.

\section{Main design ideas of the system}

\subsection{The signal control system}

The elevator signal control basically realized by PLC software implementation. The elevator signal control system is shown in FIG 1.

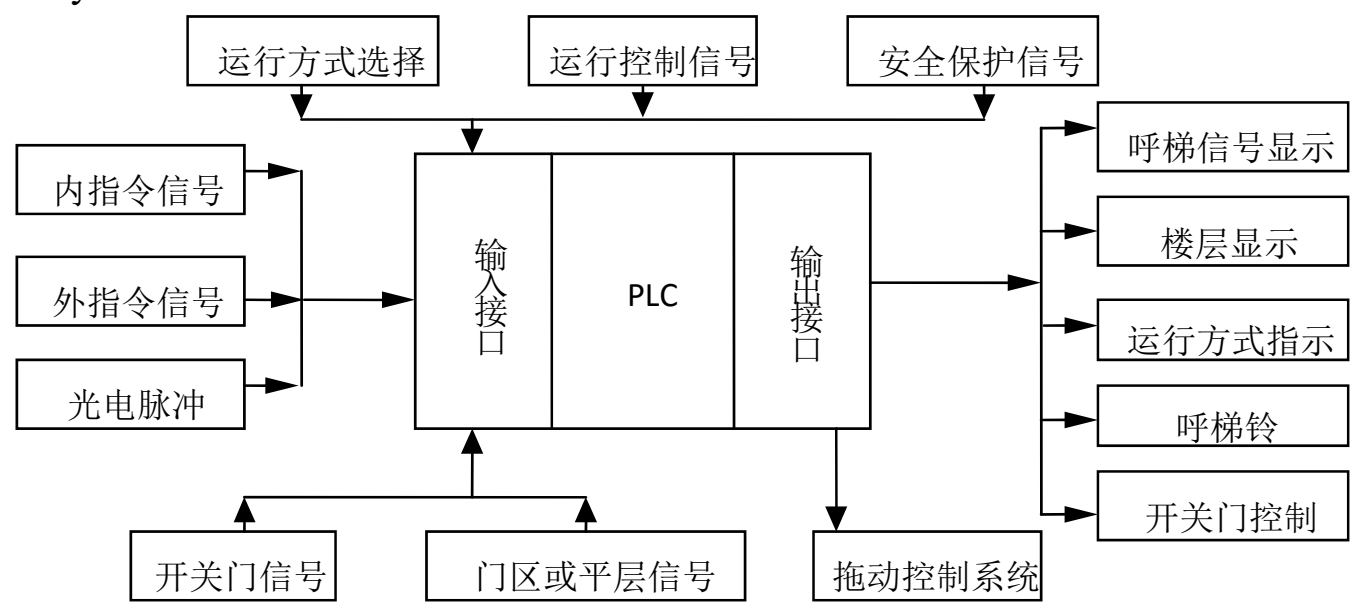

FIG 1. Elevator PLC signal control system block diagram 


\begin{tabular}{|l|l|}
\hline 运行方式选择 & Operation mode selection \\
\hline 行控制信号 & Operation control signal \\
\hline 安全保护信号 & Security protection signal \\
\hline 内指令信号 & Internal command signal \\
\hline 外指令信号 & External command signal \\
\hline 光电脉冲 & Photoelectric pulse \\
\hline 呼梯信号显示 & Elevator call signal display \\
\hline 楼层显示 & Floor display \\
\hline 运行方式显示 & Operation mode display \\
\hline 呼梯龄 & Elevator call bell \\
\hline 开关门控制 & Door control \\
\hline 拖动控制系统 & Electrical towage control system \\
\hline 门区或平层信号 & Door and leveling zone signalls \\
\hline 开关门信号 & door opening \& closing signal \\
\hline 输入接口 & Input Interface \\
\hline 输出接口 & Output Interface \\
\hline
\end{tabular}

\subsection{Deceleration and leveling control}

Working characteristics of the elevator is frequent starting and braking, In order to improve the work efficiency and improve the comfort, requiring elevator can smoothly decelerate to zero speed, accurate leveling, namely "no speed parking brake", do not appear crawling phenomenon or low speed brake, namely stop directly. As shown in FIG 2.

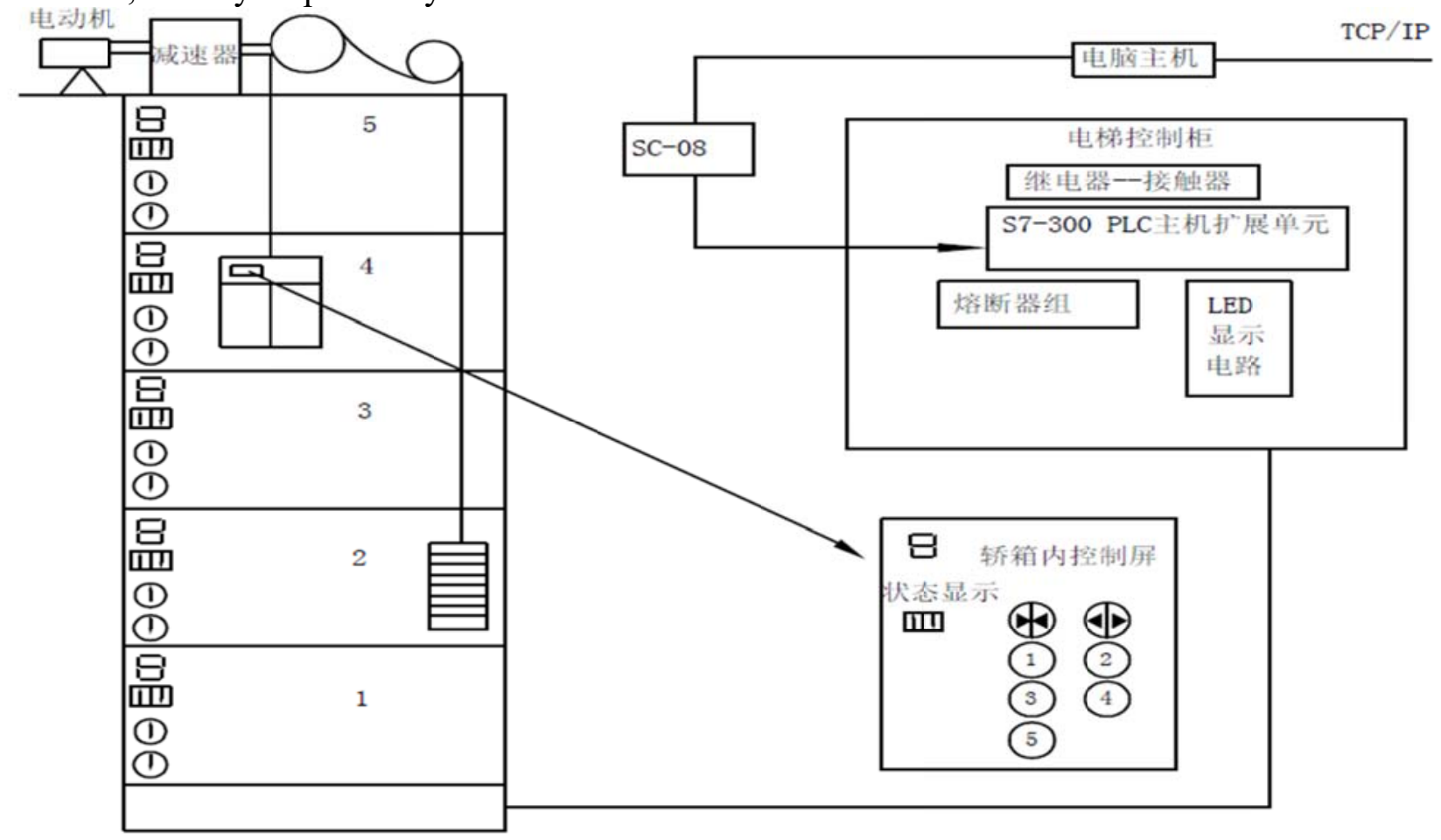

FIG 2. Five Floor Elevator controlled by PLC \& Network control schematic 


\begin{tabular}{|l|l|}
\hline 电动机 & Motor \\
\hline 减速器 & Decelerator \\
\hline 电脑主机 & Host computers \\
\hline 电梯控制柜 & Elevator control cabinet \\
\hline S7-300 PLC 主机扩展单元 & S7-300 PLC Host Extension Unit \\
\hline 熔断器组 & The fuse group \\
\hline LED 显示电路 & LED display circuit \\
\hline 轿厢内控制屏 & Car control panel \\
\hline 状态显示 & Status display \\
\hline
\end{tabular}

\subsection{For speed change and leveling sensor device}

Leveling sensor is generally used magnetic sensors, which is the same structure of permanent magnetic sensor. Permanent magnetic sensor is composed of the spring tube and the permanent magnets. Spring tube is a vacuum tube with contacts, which movable contact 2 is made of a magnetic reed, between contacts 1-2 is equivalent to a set of dynamic break contacts and contacts 2-3 is equivalent to a set of dynamic open contacts. Because of the spring tube mounted beside the permanent magnet, Under the influence of a magnetic field of the reed movement, and dynamic break contacts 1-2 open, then dynamic open contacts 2-3 open. With permanent magnetic sensors for position control of the main electric equipment, not only has the advantage of quick and reliable operation, and there is no mechanical wear defect just like limit switch.

Issued for speed change, floor and leveling signal sensor device are installed on the car, the sensor moves up and down with the car, while magnetic isolation plate fixed in the shaft, each floor of a magnetic isolation plate and those should also be installed in a precise position. When the car reaches the speed change position, speed change magnetic isolation plate inserted in the middle of speed change sensors and makes the motor slowdown. When car reaches parking floor, leveling magnetic isolation plate inserted in the middle of leveling sensors and car bottom is exactly flush with the floor. Floor signal sensor is the same principle.

\section{System control requirements analysis}

This elevator model is total five floors. Each floor of elevator has indicator light for lifting and car standby floor. 1-5 corresponding indicator light indicates floor number, each of floor hall were input (ascending and descending) button to call the elevator.Through the analysis of the above control requirements, the elevator control needs to achieve the following functions:

a.Initially, the elevator at any floor.

b. When there is hall call signals arrival elevator response to the call, and elevator stops at the floor, elevator stops running and door opens, and then closed automatically after three seconds delay.

c.Where is car call signals arrival elevator response to the call, and elevator stops at the floor, elevator stops running and door opens, and then closed automatically after three seconds delay.

d.During the elevator in the process of ascending (or descending), any descending in the opposite direction (or ascending) of hall call signal does not respond.

e.Elevator should have the farthest reverse response function for hall call signals.

f.The elevator has synthetic interception function

g.When the elevator is not leveling or running, startup button and shutdown buttons are ineffective. 


\section{PLC control system $\mathrm{I} / \mathrm{O}$ points calculation and allocation table}

According to the characteristics of the elevator control system, the input signal should include the following components:

a.Car and hall call button of each floor. There are 1-5 five numeric keys selection buttons in the car. b.Position signal.Position signal is generated by five sensors mounted the elevator stop position of each floor.

In summary, it needs a total of 18 input points. According to the characteristics of the elevator control system, the output signal should include the following components:

a.Motor indication signal: The elevator car ascending \& descending signal, traction motor forward and reverse indication signals, a total of 2 signals.

b.door opening and closing: Door open motor switch indication, totally needs 2 output points.

c.Floor display: In general elevator floor display is displayed by the digitall display tube, and this design is by the IO domain instead of digital display tube to display the floor

To sum up, it's totally need 4 output points. The hardware wiring diagram of this system is shown in FIG (3) as below.

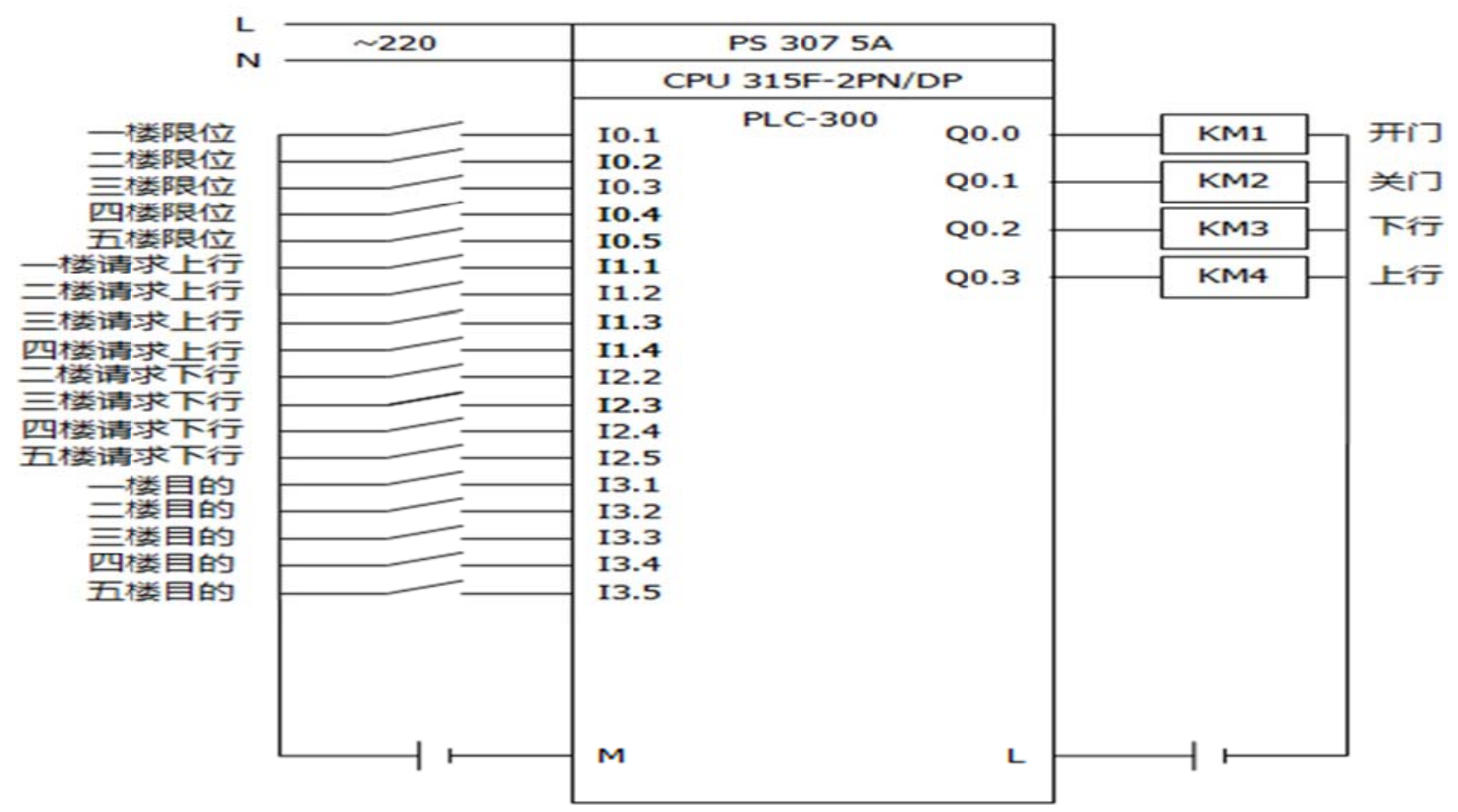




\begin{tabular}{|c|c|}
\hline 一楼限位 & First floor limit \\
\hline 二楼限位 & Second floor limit \\
\hline 三楼限位 & Third floor limit \\
\hline 四楼限位 & Fourth floor limit \\
\hline 五楼县委 & Fifth floor limit \\
\hline 一楼请求上行 & Ascending request from first floor \\
\hline 二楼请求上行 & Ascending request from second floor \\
\hline 三楼请求上行 & Ascending request from third floor \\
\hline 四楼请求上行 & Ascending request from fourth floor \\
\hline 二楼请求下行 & Descending request from second floor \\
\hline 三楼请求下行 & Descending request from third floor \\
\hline 四楼请求下行 & Descending request from fourth floor \\
\hline 五楼请求下行 & Descending request from fifth floor \\
\hline 一楼目的 & First floor destination \\
\hline 二楼目的 & Second floor destination \\
\hline 三楼目的 & Third floor destination \\
\hline 四楼目的 & Fourth floor destination \\
\hline 五楼目的 & Fifth floor destination \\
\hline 开门 & Door open \\
\hline 关门 & Door close \\
\hline 上行 & Ascending \\
\hline 下行 & Descending \\
\hline
\end{tabular}

FIG（3） PLC external wiring diagram

\section{The system software design}

The system control by random logic control. That is the elevator control requirements achieved based on the order of basic logic control. Control system design flow chart shown in FIG (4) as below. 


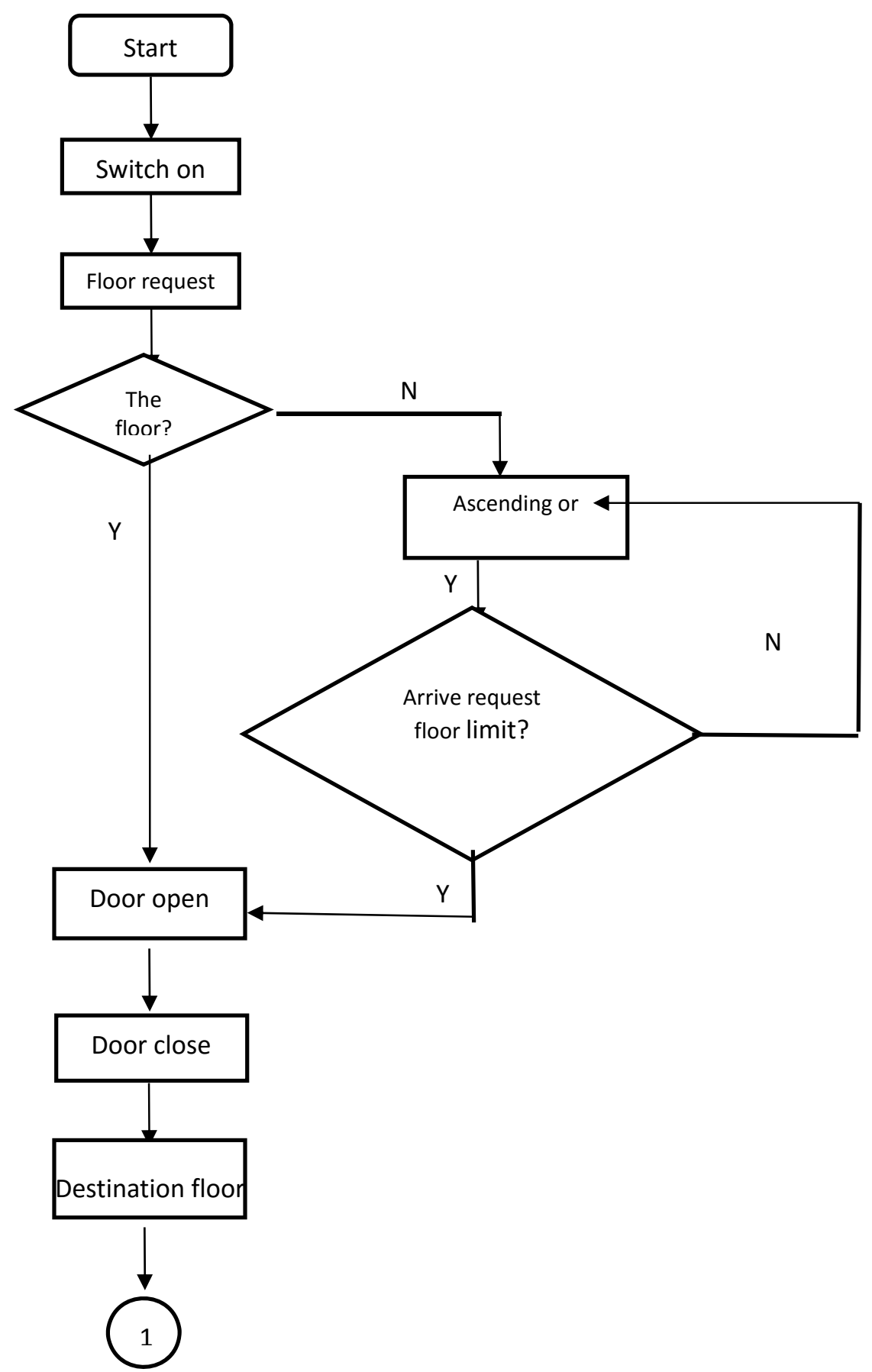




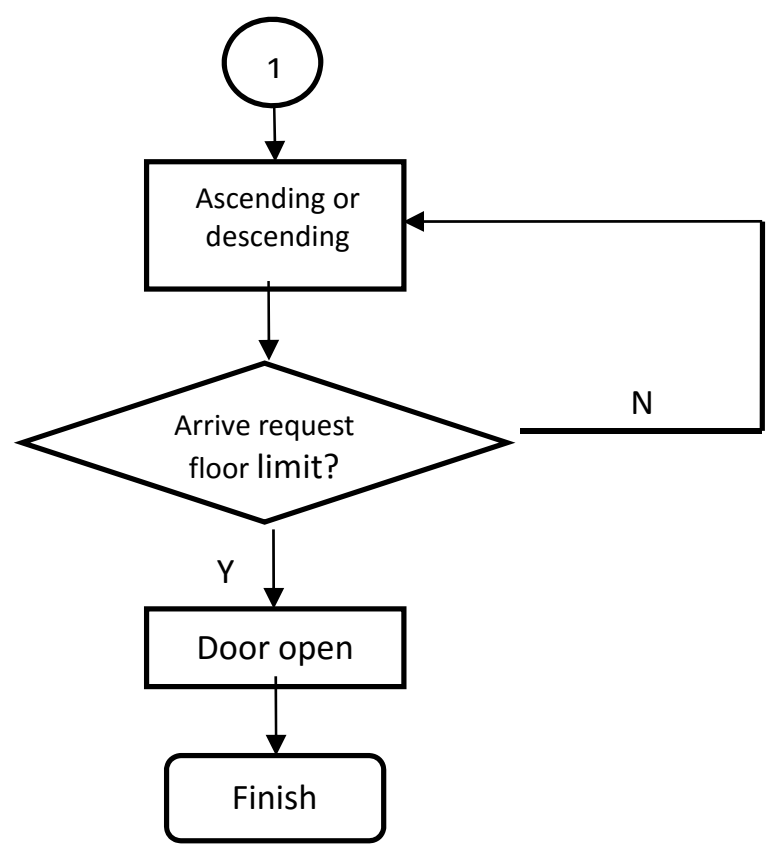

FIG (4) Control system design flow chart

\section{The elevator running status}

The car door open can be divided into the following situations:a.Elevator on the first floor leveling, there is first floor hall call for ascending indication or car call indication. b.Levator on the second floor leveling, there is second floor hall call for descending indication (elevator option descending), hall call for ascending indication (elevator option ascending) or car call indication. c.Elevator on the third floor leveling, there is third floor hall call for descending indication(elevator option descending), hall call for ascending indication (elevator option ascending) or car call indication.d.Elevator on the fourth floor leveling, there is fourth floor hall call for descending indication(elevator option descending), hall call for ascending indication (elevator option ascending) or car call indication.e.Elevator on the fifth floor leveling, there is fifth floor hall call for descending indication or car call indication. f.When elevator on the leveling, pressing the door open button.

\section{References}

[1] PLC application technology. Changchu Liao. Chongqing University Press.

[2] The programming methods and engineering application of PLC. Changchu Liao. Chongqing University Press.

[3] PLC ladder diagram program design methods and skills. Changchu Liao. Electrotechnics.

[4] Electrical and PLC application technology. Zeming Deng, Shuifang Deng, etc. China Machine Press.

[5] Large PLC System Design. Shaowu Zhou, etc. China Electric Power Press.

[6] The principle and application of PLC. Xuelin Hu. Publishing House Of Electronics Industry.

[7] The PLC theory and experiment. Wenhao Zhang. National Defence Industry Press.

[8] Small PLC practical technology. Zhaoyi Wang. China Machine Press.

[9] The principle and application of PLC. Zhifeng Wang. University Of Electronic Science And Technology Press.

[10] li Wu, Yubin Liu Simons S7-300PLC basis and application. China Machine Press.

[11] Jian Simons S7 PLC_-STEP7 Programming Guide [M]. China Machine Press. Beijing (in Chinese) 